\section{International Scientific Journal}

\section{Theoretical \& Applied Science}

p-ISSN: 2308-4944 (print) e-ISSN: 2409-0085 (online)

Year: $2014 \quad$ Issue: 11 Volume: 19

Published: $30.11 .2014 \quad$ http://www.T-Science.org
EInur Latif oglu Hasanov

Corresponding member of International Academy of Theoretical and Applied Sciences,

Ph.D. postgraduate

Institute of Local-lore of Ganja Branch Azerbaijan National Academy of Sciences,

Ganja, Azerbaijan

1-hasan@hotmail.com

SECTION 12. Geology. Anthropology. Archaeology.

\title{
SIGNIFICANCE OF MULTIDISCIPLINARY RESEARCH OF HANDICRAFT PATTERNS OF GANJA ON THE BASIS OF BIOCHEMICAL METHODS
}

\begin{abstract}
In scientific work for the first time has been researched the significance of traditional craftsmanship patterns from ethnographic and archaeological point of view in investigation of development of features of urban culture in Ganja on the basis of scientific arguments. Were noted the main results of investigations of local researchers in this field with scientists from the USA and Japan on the basis of application of innovative technologies and methods. These scientific investigations have a great applicative significance. It is possible of production of these handicraft wares for ancient, classical and Mediavel periods on the basis of its production technology and materials in the modern time as new models.

Key words: Ganja, historic-ethnographical research, traditional handicraft kinds, innovative research methods, features of urban culture, Azerbaijan.

Language: English

Citation: Hasanov EL (2014) SIGNIFICANCE OF MULTIDISCIPLINARY RESEARCH OF HANDICRAFT PATTERNS OF GANJA ON THE BASIS OF BIOCHEMICAL METHODS. ISJ Theoretical \& Applied Science 11 (19): 41-43. doi: http://dx.doi.org/10.15863/TAS.2014.11.19.8
\end{abstract}

\section{Introduction}

In the territory of ancient Ganja during the end of 2012 - in 2013 have been carried out scientific researches, archaeologic and ethnographical investigations by local scientists together with researchers from National Museum of Natural History of Smithsonian Institution of the USA and Tokio Museum University of Japan with the purpose to study of historical formation and development of Urban culture. Because, one of the areas of initially appeared human civilization was an integral part of Azerbaijan, the historical land of the city Ganja. Scientific and archaeological researches have proved that Ganja was cradle of science and culture not only of Azerbaijan, but also of the whole East. The majority of historical monuments, that are demonstrate the ancient history of Ganja, which is the national wealth of our people, today gain unique place in the expositions of World's museums. In state and private museums of Metropolis, Munich, Berlin, Hamburg, Louvre, Paris, Moscow, St. Petersburg and other cities rare and valuable exhibits, that concern to the history of ancient Ganja are preserved (Taylor P and Hasanov E, 2013). Ganja city that located on an altitude of 400-450 meters above sea level is situated on the west of Azerbaijan, 375-kms to the west from the capital city Baku, on Ganja-Kazakh plain, that located in the Kura - Araz lowland, at the foot of the Lesser Caucasus on the north-east. Ganja, that has changed its location at least 4 times since its establishment, is located in a favorable position from the strategic point of view. That why it always has been the center of attention of foreigners. Ganja, that was the victim of a terrible earthquake many times, also was the subject of attacks of Mongols, Kharezms, Georgians, Arabs, Russians and other invaders. Ganja has turned to the arena of war damage of different countries of the World. But in spite of it didn't shaken, and using the genetic power revived and developed, and rose to the level of great cities.

\section{Goals and objectives of research}

The main aim of our international investigations for the second half of 2013 with scientists from the US and Japan is research of significance of local traditional handicraft patterns as a source in research of features of urban culture in Ganja. As known, Ganjabasar is one of the richest areas from archaeological point of view. As a result of 
archaeological investigations here were found samples of material culture that concerned to the stages of different history period. Today most of them are kept in various museums of the World.

The flint tools, that found in Gillikdag workshop and camp around Ganja, ladle, that were found here give the reason to say, that people, who lived in this area in VII - VI millennium BC were the founders of the Neolithic Age culture.

Archaeological investigations prove that in this period the main population of this region had sedentary lifestyle and were engaged with farming. In $\mathrm{V}$ millennium $\mathrm{BC}$ in Ganja region all known to us domestic animals were domesticated. This fact is approved with ostheology remainders that were found during archaeological excavations. The anonymous author of the article "Russian city" gave the schedule indicating the date of cities of the South Caucasus, also of Azerbaijan. And here he matched, that Ganja was founded in II century BC - IV centuries. The same words that match that Ganja is older than Barda and Beylagan prove Qagemeyster's information and conception that says "At a short distance from Barda another city was also flowering, which at the time of destruction substituted it. It was Ganja city. Their origin, probably, was the same ... " (Azerbaijan ethnography, 2007).

Basic objective of research is outreach, also publish in international academic journals of the main results of scientific researches in this field on the basis of application of innovative technologies and methods. Research of traditional wares of handicraft kinds of Ganja on the basis of innovative methods is very important and necessary. The increase in quantity of handicraftsmen in a city directly has been bundled to population growth. Closely bundled to an economy and a daily life of the people, craft employment were one of the basic carriers of national traditions. The competition of production of production plants and factories has not reached still serious level and consequently was created a favorable condition for spreading of traditional occupations there. In addition, products of these craft branches have been closely bundled to a life and traditions of the people, and it would be difficult to replace with their factory production (Guliyeva N and Häsänov E, 2014). In the specified period of history in Ganja developed basically carpet weaving, weaver's business, craft of the tailor, squeeze men, forge and a jeweler, trades of dyer, the stone mason, the cooper and leather dresser, weapon business and other similar craft branches (Taylor $\mathrm{P}$ and Hasanov E, 2013).

Investigation of the main traditional craft branches on the basis of new, innovative methods and technologies is very important. Results of these researches show the significance of different patterns of craftsmanship kinds as a source in studying of historical past of nations. Studying of craft problems actually and in the modern world in sense of the decision of professional problems. From the investigated national employment carpet weaving, the jeweler, a stone dressing and strenuously develop on the basis of ancient traditions already dying out ancient trades, such as a pottery and an art embroidery. Each area of Azerbaijan possesses characteristic environmental resource bases for it and it promoted development of various crafts.

From the construction point of view, samples of pottery, that concern to Antique period, also to the period of Hellenism in Ganja, differed in various forms as pictorial vases, ceramic figures, connected dishes. During the end of Middle Ages and New Period in Ganja and its regions ceramic has following kinds as building ceramic materials, unglazed ceramic products, glazed ceramic products. For Middle Ages and New period among pottery products of Ganja ceramic samples as clay construction materials have great importance. First of all, glazed bricks that used in construction of most buildings in the XVII-XVIII centuries, and also in great monuments and the main construction material - air-dried bricks, attracted attention. In addition to the found samples in residential areas as a result of archaeological excavations, also were found a lot of brick spoilages. According to such kind mass finding of brick spoilages, we can make the conclusion, that the bricks used in construction of buildings in Ganja, were wares of local production.

\section{Solving methods of problem and testing}

During these scientific investigations have been used some main innovative academic methods:

1. Application of biochemical innovative technologic methods (as radiocarbon, dendrochronologic methods and etc.);

2. Research of local materials of craftsmanship patterns;

3. Determination of traditional methods and materials of handicraft wares on the basis of innovative roads;

4. For the first time research of problem of genesis of handicraft traditions on the basis of production technology and technique of local craftsmanship patterns of ancient and classical periods;

5. Foundation of the new scientific direction on ethnography and ethnology on the basis of investigation of sustainable historical features of handicraft branches in research of the historical past of formation and development of Urban culture;

6. Investigation of importance of the handicraft patterns as the main source in research of characteristics of formation and development of Urban culture (formation process of the features of urban culture) for ancient and classical periods on the basis of scientific arguments. 


\section{Discussion of results and applicative significance}

a) For the first time has been researched the significance of traditional craftsmanship patterns from ethnographic and archaeological point of view in investigation of development of features of urban culture in Ganja on the basis of scientific arguments.

b) Were noted the main results of investigations of local researchers in this field with scientists from the USA and Japan on the basis of application of innovative technologies and methods.

c) In the future it would help to continue the both scientific-research works, also ethnographic and archaeological investigations, excavations and for the main academic results in this field.

d) These scientific investigations have a great applicative significance. It is possible of production of these handicraft wares for ancient, classical and Mediavel periods on the basis of its production technology and materials in the modern time as new models.

\section{Conclusion}

Local, traditional handicraft wares of Ganja for ancient, classical and Mediavel periods for the first time have been researched.

For the first time in the territory of ancient Ganja have been carried out scientific researches, archaeologic and ethnographical investigations by local scientists together with researchers from National Museum of Natural History of Smithsonian Institution of the USA and Tokio Museum University of Japan with the purpose to study of historical formation and development of Urban culture.

Importance of typical local wares of handicraft branches of Ganja was investigated for the first time in research of historical formation and development of the main Urban culture elements and construction feature - craftsmanship blocks (quarters).

\section{References:}

1. Ohmədov FM (2007) Gəncənin tarix yaddaşı. Gəncə: Elm.

2. Bünyadova ST (1992) Nizami vo etnoqrafiya. Bakı: Elm.

3. Burton-Brown $\mathrm{T}$ (1951) Excavations in Azerbaijan, 1948. London

4. Ofəndiyev RS (1966) Azarbaycanın badii sənətkarlığı. Bakı: Azərnəşr.

5. Guliyeva NM, Häsänov EL (2014) Die traditionelle Gändschänischen Teppiche von Zeitraum der Aserbaidschanischen Gelehrten und Dichter Mirsä Schäfi Waseh als ethnoanthropologische quelle (XIX Jahrhundert). European Applied Sciences, 2: 3-5.

6. Hasanov EL (2013) About fundamental studies on local cultural traditions of Ganja. European Journal of Natural History, 3: 65-68.

7. Hasanov EL (2014) Approccio innovativo per lo studio scientifico delle tradizioni artigianali grandi Ganja seconda metà del XIX-inizi XX secolo. Italian Science Review, 4: 642-645.
Available at URL: http://www.iasjournal.org/archive/2014/april/Hasanov.pdf.

8. Həmidova İ (2000) Azərbaycan parça sənətinin tarixi inkişaf yolları. Elmi axtarışlar, VIII toplu, Bak1.

9. Həvilov HA (1991) Azarbaycan etnoqrafiyast. Bakı: Elm.

10. Nishiaki Y, Hasanov EL (2014) About ethnoarchaeological and anthropological research of some prehistoric monuments of Ganja. ISJ Theoretical \& Applied Science 1 (9): 45-48. doi:

http://dx.doi.org/10.15863/TAS.2014.01.9.8

11. Taylor PM, Hasanov EL (2013) Ethnological features of cultural heritage of Ganja (On the basis of Mahsati Ganjavi's creation). ISJ Theoretical \& Applied Science 12 (8): 41-44. doi: http://dx.doi.org/10.15863/TAS.2013.12.8.10

12. Tərlanov M, Ofəndiyev R (1960) Azərbaycan xalq sənəti. Bakı: Uşaq gənc nəşr. 